\title{
Distribusi Vertikal Karbon Monoksida di Sumatera Berdasarkan Pengamatan Measurement of Pollution in the Troposphere (MOPITT) Selama Kebakaran Hutan Tahun 2015
}

\author{
Ulfa Azmi, Marzuki* \\ Jurusan Fisika FMIPA Universitas Andalas, Padang \\ Kampus Unand Limau Manis, Pauh Padang 25163 \\ *marzuki@fmipa.unand.ac.id
}

\begin{abstract}
ABSTRAK
Distribusi vertikal karbon monoksida (CO) di Sumatera selama kebakaran hutan tahun 2015 telah diteliti menggunakan data satelit MOPITT (Measurements of Pollution in the Troposphere). Pengaruh proses konveksi terhadap pergerakan CO ke lapisan atmosfer diamati dengan data OLR (Outgoing Longwave Radiation) dan pergerakan udara dari data NCEP/NCAR (National Centers for Environmental Prediction/National Center for Atmospheric Research). Hasil penelitian memperlihatkan bahwa kebakaran hutan tahun 2015 telah meningkatkan konsentrasi CO di Indonesia. Namun, jumlah gas CO yang terekam oleh MOPITT tidak terlalu tinggi ( 40-120 ppbv). Hal ini disebabkan oleh tingginya konsentrasi uap air di ekuator sehingga konsentrasi $\mathrm{CO}$ rendah dan waktu tinggal $\mathrm{CO}$ di atmosfer juga berkurang. Selain di permukaan, peningkatan konsentrasi CO juga teramati pada lapisan atmosfer yang lebih tinggi. Namun, hubungan antara pergerakan $\mathrm{CO}$ ke lapisan atmosfer atas dengan aktivitas konveksi sulit untuk diamati dengan data satelit MOPITT. Perulangan waktu pengamatan MOPITT untuk titik pengamatan yang sama cukup lama yaitu 4 hari menjadi salah satu kendala. Walaupun demikian, dari tiga studi kasus yang diteliti, teramati pengaruh konveksi terhadap pergerakan CO ke atas pada dua kasus yaitu tanggal 11 dan 15 Oktober 2015. Pada 11 Oktober, jumlah CO bertambah dari 60 ppbv menuju 80100 ppbv dan pada tanggal 15 Oktober, juga mengalami peningkatan dari 60 ppbv menjadi $80-90$ ppbv pada $100 \mathrm{hPa}$.
\end{abstract}

Kata kunci:CO, MOPITT, konveksi, Sumatera, kebakaran hutan 2015

\begin{abstract}
The vertical distribution of carbon monoxide (CO) over Sumatra during the 2015 forest fire had been investigated by using the data of MOPITT (Measurements of Pollution in the Troposphere). The possible effect of convective process on the vertical transport of CO from the surface to the upper atmosphere was studied by using the OLR (Outgoing Longwave Radiation) and air motion data of NCEP/NCAR (National Centers for Environmental Prediction/National Center for Atmospheric Research). It was found that the forest fire had increased the CO concentration in Sumatra. However, the concentration was still lower ( 40-120 ppbv) than high latitude region that may be due to high concentration of water vapor in the equator. The increase of CO concentration was observed not only at the surface, but also at upper atmosphere. The effect of convective process on the vertical transport of $\mathrm{CO}$ was difficult to be observed using the MOPITT data because of its low temporal resolution. However, of three cases examined the effect of convective process was observed for two cases, namely during 11 and 15 October. During 11 October, CO concentration increased from 60 ppbvto 80-100 ppbv and it increased from 60 ppbv to 8090 ppbv at $100 \mathrm{hPa}$ during 15 October.

Keywords:carbon monoxide, MOPITT, convective, 2015 forest fire, Sumatra
\end{abstract}

\section{PENDAHULUAN}

Karbon monoksida (CO) merupakan senyawa berwujud gas yang tidak berwarna, tidak berbau, tidak berasa, mudah terbakar dan tidak mengiritasi namun sangat beracun (Rivanda, 2015). Gas CO sangat berbahaya bagi kehidupan manusia karena sifat CO yang lebih cepat mengikat hemoglobin menjadi carboxyhemoglobin sehingga menghambat aliran oksigen $\left(\mathrm{O}_{2}\right)$ untuk masuk ke dalam tubuh. Jika konsentrasi $\mathrm{O}_{2}$ kurang dari $14 \%$ dari ambang batas yang diperbolehkan maka dapat menyebabkan resiko kematian (Zulfa, 2011). Selanjutnya Kumar (2013) menambahkan bahwa gas CO secara tidak langsung mempengaruhi konsentrasi gas rumah kaca seperti metana dan ozon di troposfer. Hal ini disebabkan karena gas $\mathrm{CO}$ menghapus oksidan utama troposfer yaitu radikal $\mathrm{OH}$ yang memiliki peran penting sebagai agen pembersih atmosfer (Srivastava dan Sheel, 2013). 
Gas CO dapat terbentuk secara alamiah tetapi sumber utamanya adalah aktivitas manusia. Karbon monoksida yang terbentuk secara alamiah berasal dari letusan gunung berapi dan oksidasi gas metana di atmosfer. Gas CO yang bersumber dari kegiatan manusia berasal dari hasil pembakaran tidak sempurna bahan bakar fosil seperti kendaraan bermotor dan industri (Richards, 2004). Selain itu, CO juga dapat terbentuk dari hasil pembakaran biomassa seperti kebakaran hutan dan lahan (Girach dan Nair, 2014a). Hasil penelitian Vadrevu dkk. (2013) menunjukkan terjadinya peningkatan konsentrasi $\mathrm{CO}$ akibat dari kebakaran hutan di India Timur Laut dengan rata-rata CO sebesar 244,85 ppbv setiap bulannya. Menurut Canadian Space Agency (2016) kadar alami gas CO di atmosfer bawah adalah 100 ppbv.Sumatera merupakan salah satu pulau terbesar di Indonesia yang sering mengalami kebakaran hutan. Berdasarkan data Global Forest Watch (2016), sepanjang tahun 2015 telah terjadi kebakaran hutan besar di beberapa provinsi di Sumatera. Hal ini disebabkan oleh pembakaran liar dari pembukaan lahan yang didukung oleh musim kemarau panjang sehingga pulau Sumatera tertutup kabut asap selama beberapa bulan. Akibat tingginya jumlah angka kebakaran didukung proses konveksi yang kuat akibat musim kemarau diperkirakan konsentrasi gas $\mathrm{CO}$ di atmosfer juga akan meningkat.

Distribusi karbon monoksida di atmosfer mencakup pergerakan gas CO secara horizontal dan vertikal. Girach and Nair (2014b) menambahkan bahwa distribusi CO dipengaruhi oleh faktor meteorologi baik secara vertikal maupun horizontal. Faktor-faktor meteorologi tersebut mencakup arah dan kecepatan angin serta kemunculan awan konvektif. Indonesia merupakan negara beriklim tropis sehingga menerima radiasi matahari yang sangat besar. Akibat besarnya radiasi matahari tersebut menyebabkan proses konveksi yang terjadi di seluruh wilayah Indonesia khususnya Sumatera akan semakin kuat (Marzuki dkk., 2013, 2016a) yang ditandai tingginya curah hujan di kawasan ini (Marzuki dkk, 2016b). Proses konveksi yang sangat kuat ini menyebabkan terjadinya pergerakan gas $\mathrm{CO}$ secara vertikal ke lapisan troposfer atas. Srivastava dan Sheel (2013) menunjukkan bahwa terjadi peningkatan CO sebesar 100-250 ppbv di troposfer atas sebagai akibat proses konveksi di wilayah Indonesia. Namun, penelitian mengenai dampak konvektif terhadap pergerakan arah vertikal $\mathrm{CO}$ masih sangat terbatas. Oleh karena itu, tulisan ini membahas distribusi vertikal karbon monoksida di Sumatera berdasarkan pengamatan MOPITT selama kebakaran hutan tahun 2015.

MOPITT merupakan sensor data satelit Terra yang secara bersamaan dapat memonitor emisi gas CO dan metana di atmosfer. Selain itu, MOPITT juga menyediakan data akurat mengenai distribusi gas $\mathrm{CO}$ di atmosfer yang meliputi distribusi spasial, temporal dan vertikal. Beberapa penelitian tentang monitoring emisi gas CO telah dilakukan oleh Liu dkk. (2005); Gonzi dkk. (2011); Vadrevu dkk. (2013); Girach dan Nair (2014a). Hasil penelitian Liu dkk. (2005) menunjukkan bahwa MOPITT dapat dipercaya mendeteksi gas CO dari kebakaran hutan di Barat Laut Amerika. Selain itu, untuk melihat pengaruh proses konveksi terhadap proses pergerakan gas CO akan diamati dengan menggunakan data OLR. Data OLR dapat dijadikan indikator kemunculan awan konvektif. Pengaruh angin vertikal terhadap perpindahan CO dapat diamati dengan menggunakan data dari NCEP/NCAR (Girach dan Nair, 2014b).

\section{METODE}

Data yang digunakan dalam penelitian ini adalah data konsentrasi $\mathrm{CO}$ hasil pengamatan sensor satelit MOPITT V6-TIR / NIR level3 yang mempunyai resolusi waktu 1 hari dan resolusi spasial $22 \mathrm{kmx} 22 \mathrm{~km}$. Selain itu diambil juga data pergerakan udara (omega) dari NCEP/NCAR dan data OLR dengan resolusi waktu 1 hari dan resolusi spasial data adalah $2,5^{\circ}$. Data diambil selama 1 tahun dalam periode Januari-Desember 2015 termasuk bulan terjadinya kebakaran hutan Sumatera. Jumlah hotspot selama kebakaran hutan tersebut dapat dilihat pada Gambar 1. 


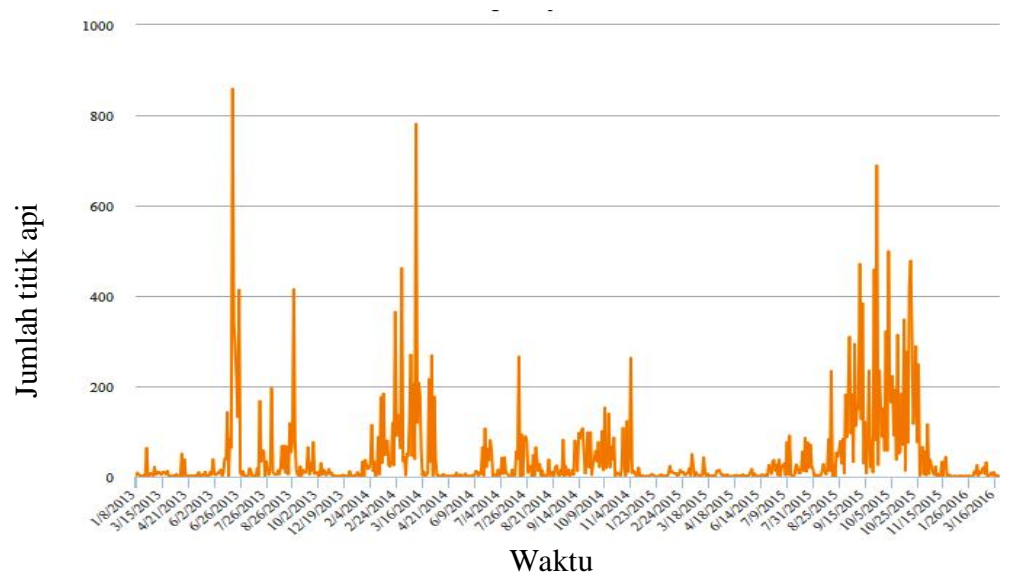

Gambar 1 Jumlah titik api tahun 2015

(Sumber : Global Forest Watch, 2016)

Dalam penelitian ini pengolahan data menggunakan software MATLAB versi R2013. Data yang diunduh mewakili data untuk seluruh dunia, selanjutnya diseleksi sesuai dengan titik koordinat daerah penelitian (Pulau Sumatera) yaitu $7,5^{\circ} \mathrm{LU}-7,5^{\circ} \mathrm{LS}$ dan $90^{\circ} \mathrm{BT}-110^{\circ} \mathrm{BT}$. Dalam data MOPITT terdapat file yang berisi datafield gas CO. Pada datafield tersebut terdapat beberapa macam file data $\mathrm{CO}$ yang dipilih adalah AprioriCOMixingRatioPofile, sebab data tersebut mencakup jumlah $\mathrm{CO}$ pada 9 ketinggian atau tekanan dengan satuan ppbv. Selanjutnya, data yang sudah dipilih ditampilkan dalam bentuk kontur. Pola yang diperoleh nantinya akan berisi total gas $\mathrm{CO}$ pada 9 tekanan terhadap waktu pengamatan.

Data angin vertikal dari NCEP dan data awan konvektif dari OLR berbentuk data grid dengan format NetCDF. Data dibaca dengan NetCDF library yang ada di MATLAB. Data tersebut juga untuk seluruh dunia, kemudian dipilih data yang sesuai dengan daerah penelitian. Data ini diplot dalam bentuk kontur selama periode pengamatan yang sama dengan data CO.

Data di plot adalah dalam bentuk time series baik data MOPITT, data OLR, dan data NCEP/NCAR selama Januari-Desember 2015. Selanjutnya ditambahkan dengan plot studi kasus untuk memperkuat hasil sebelumnya. Studi kasus yang dipilih adalah bulan terjadinya kebakaran hutan dan saat terjadinya aktivitas konveksi yang kuat serta pada waktu MOPITT melewati daerah Sumatera dan sekitarnya.

Distribusi vertikal CO tersedia dalam 9 tekanan yaitu dari 900, 800, 700, 600, 500, 400, 300, 200, $100 \mathrm{hPa}$. Data konsentrasi CO ini akan dianalisis tiap tekanan, untuk mengetahui jumlah konsentrasi $\mathrm{CO}$ yang berpindah dari lapisan bawah ke lapisan yang lebih tinggi atau dari tekanan yang paling tinggi ke tekanan yang lebih rendah. Apabila terdapat jumlah gas $\mathrm{CO}$ yang tinggi pada lapisan atas daripada lapisan bawah, maka hal tersebut nantinya akan dikorelasikan dengan faktor-faktor yang mempengaruhi distribusi CO secara vertikal. Faktor - faktor tersebut adalah angin vertikal dan awan konvektif. Apabila nilai dari awan konvektif yang diperoleh dari data OLR kurang dari $220 \mathrm{Wm}^{-2}$, ini mengindikasikan adanya aktivitas konvektif dalam (deep convective) (Girach dan Nair, 2014b). Selanjutnya, apabila kecepatan angin vertikal ke atas (omega) meningkat pada waktu terdapatnya gas CO di lapisan atas, ini juga dapat mengindikasikan adanya aktivitas konvektif dalam (deep convective). Jika terdapat hubungan antara konsentrasi CO dan faktor-faktor di atas, maka peningkatan konsentrasi CO di troposfer atas dapat disebabkan oleh faktor tersebut. Sebaliknya, apabila tidak terlihat hubungan yang jelas, maka ada kemungkinan faktor lain menjadi penyebab tinggi atau rendahnya gas CO pada lapisan troposfer atas.

\section{HASIL DAN DISKUSI}

\subsection{Time Series CO, OLR, dan Omega selama 2015}

Gambar 2a memperlihatkan time series distribusi vertikal dari mixing ratio $\mathrm{CO}$ untuk siang hari dari data MOPITT level 3 V6 (TIR/NIR) selama Januari-Desember 2015 yang dirataratakan dalam grid $-7.5^{\circ}$ LU-7, $5^{\circ}$ LS dan $90^{\circ}$ BT- $110^{\circ}$ BT (sekitar Sumatera). Selain itu diplot 
juga timeseries data omega (Gambar 2b) dan timeseries data OLR (Gambar 2c) dari NCEP/NCAR. Omega dan OLR merupakan data harian. Omega dengan nilai negatif menandakan pergerakan udara ke atas sedangkan yang positif menandakan pergerakan udara ke bawah. Untuk OLR, semakin kecil nilainya semakin menggambarkan kemunculan awan-awan konvektif. Nilai-nilai OLR yang tinggi menandakan awan-awan rendah yang dominan atau awan-awan tinggi tidak ada.

Secara umum jumlah gas CO yang terekam oleh MOPITT selama kebakaran di tahun 2015 tidak terlalu tinggi hanya berkisar antara 40-120 ppbv. Richard (2004) melaporkan bahwa mixing ratio dari $\mathrm{CO}$ relatif konstan di daerah tropis. Hal tersebut diperkuat oleh hasil penelitian Girach dan Nair (2014b) yang mengatakan konsentrasi CO rendah di sekitar daerah ekuator $\left(<5^{\circ}\right.$ LU) karena ada sumber lain yang menyebabkan berkurangnya konsentrasi CO seperti uap air. Uap air diketahui merupakan sumber utama pembentuk radikal $\mathrm{OH}$. Apabila $\mathrm{OH}$ tinggi, maka konsentrasi $\mathrm{CO}$ rendah sehingga waktu tinggal $\mathrm{CO}$ di atmosfer juga berkurang.

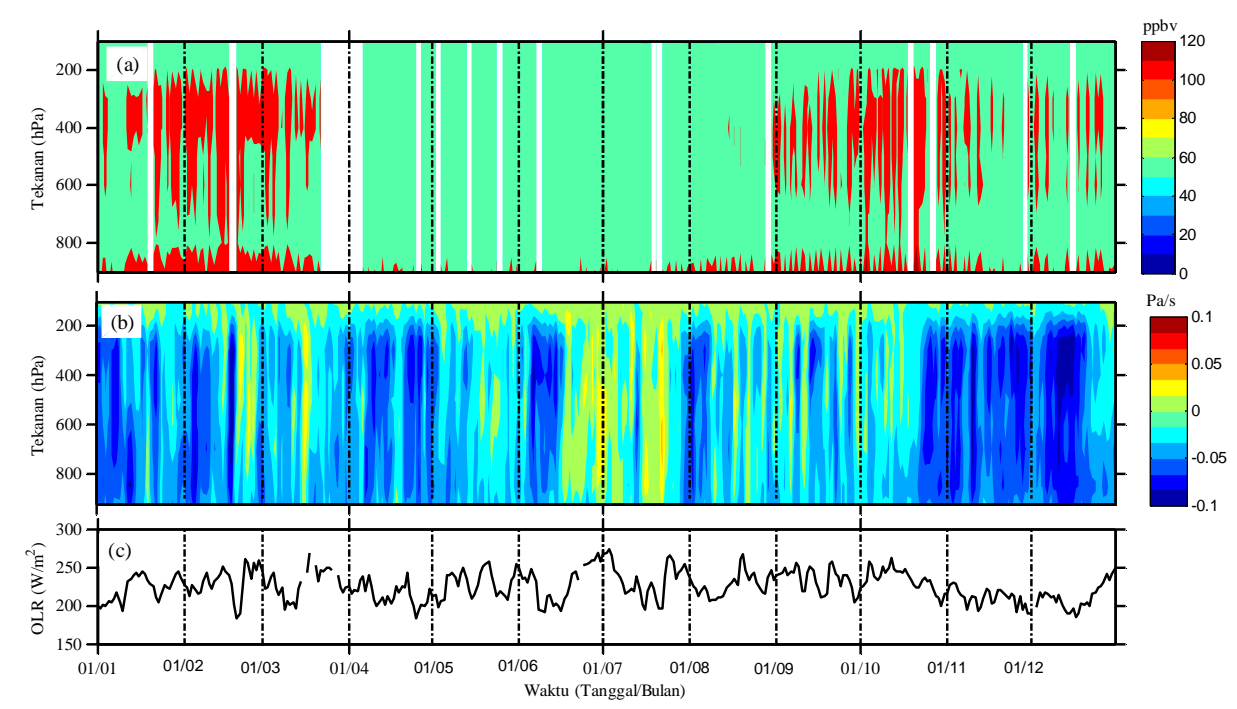

Gambar 2 Time series (a) mixing ratio profile CO level 3 (V6-TIR/NIR) siang hari (b) Omega (c) OLR selama Januari-Desember 2015 (tidak berwarna = missing data)

Data CO siang hari berkisar antara 60-110 ppbv, sedangkan pada malam hari (tidak ditampilkan) berkisar antara 30-100 ppbv. Hal ini disebabkan pada siang hari aktivitas manusia lebih banyak sehingga CO lebih tinggi di siang hari daripada malam hari. Selain itu, banyak data yang tidak terekam pada malam hari karena MOPITT tidak dapat memonitor konsentrasi gas CO apabila tertutup awan. Pada malam hari lebih banyak terbentuk awan konvektif dibandingkan siang hari karena hujan lebih sering terjadi pada sore dan malam hari (Mori dkk.,2004). Pengamatan satelit MOPITT juga lebih sensitif pada siang hari daripada malam hari sehingga banyak data yang tidak terekam pada malam hari (Kar dkk., 2004). Oleh sebab itu, data CO pada malam hari tidak bisa dipakai pada pembahasan berikutnya.

Profil CO baik pada siang atau malam hari memperlihatkan bahwa jumlah $\mathrm{CO}$ menurun dari tekanan $800 \mathrm{ke} 600 \mathrm{hPa}$, kemudian meningkat lagi pada $500 \mathrm{hPa}$ hingga $200 \mathrm{hPa}$. Hal ini diakibatkan oleh pengamatan konsentrasi CO oleh MOPITT lebih sensitif di lapisan troposfer atas. Jumlah CO yang tertinggi biasanya terjadi pada tekanan 350 hPa (Kar dkk., 2004). Oleh sebab itu, gas CO kurang teramati pada tekanan 800 hingga $600 \mathrm{hPa}$.

Kebakaran hutan di Sumatera dimulai pada September dan hal itu juga ditandai dengan peningkatan CO terutama pada bulan September-November. Hal ini konsisten dengan jumlah titik api dimana pada bulan September-November sangat tinggi jumlahnya dibandingkan dengan bulan-bulan yang lain seperti terlihat pada Gambar 1.

Selain peningkatan CO di permukaan, selama September-November terlihat juga peningkatan konsentrasi CO pada ketinggian di atas $600 \mathrm{hPa}$, terutama pada siang hari (Gambar 2). Kar dkk (2004) menyebutkan bahwa peningkatan jumlah CO pada lapisan troposfer atas atau pada tekanan yang lebih rendah disebabkan karena adanya aktivitas konvektif dalam (deep 
convective). Aktivitas konvektif tersebut dapat diidentifikasi dengan data angin vertikal (data omega) dan data awan konvektif (data OLR). Secara umum, sulit untuk mengamati hubungan yang signifikan antara data $\mathrm{CO}$ dengan data omega maupun antara $\mathrm{CO}$ dengan data OLR (Gambar 2). Hubungan antara ditribusi vertikal CO dengan data omega kurang sesuai. Misalnya, pada bulan Agustus-September terjadi pergerakan CO ke lapisan troposfer yang lebih tinggi namun atmosfer justru bergerak ke arah bawah (nilai omega positif), bukan ke atas (nilai omega negatif). Selain itu, pada bulan November-Desember juga teramati pergerakan atmosfer ke atas sekitar $0,1 \mathrm{~Pa} / \mathrm{s}$ tetapi distribusi vertikal $\mathrm{CO}$ kurang terlihat pada bulan tersebut. Melalui time series hubungan antara distribusi vertikal CO dengan awan konvektif (data OLR) juga sulit teramati. Misalnya, pada bulan September-Oktober OLR bernilai lebih dari $220 \mathrm{~W} / \mathrm{m}^{2}$ yang berarti tidak ada awan konvektif tetapi distribusi vertikal $\mathrm{CO}$ justru tinggi pada bulan-bulan tersebut.
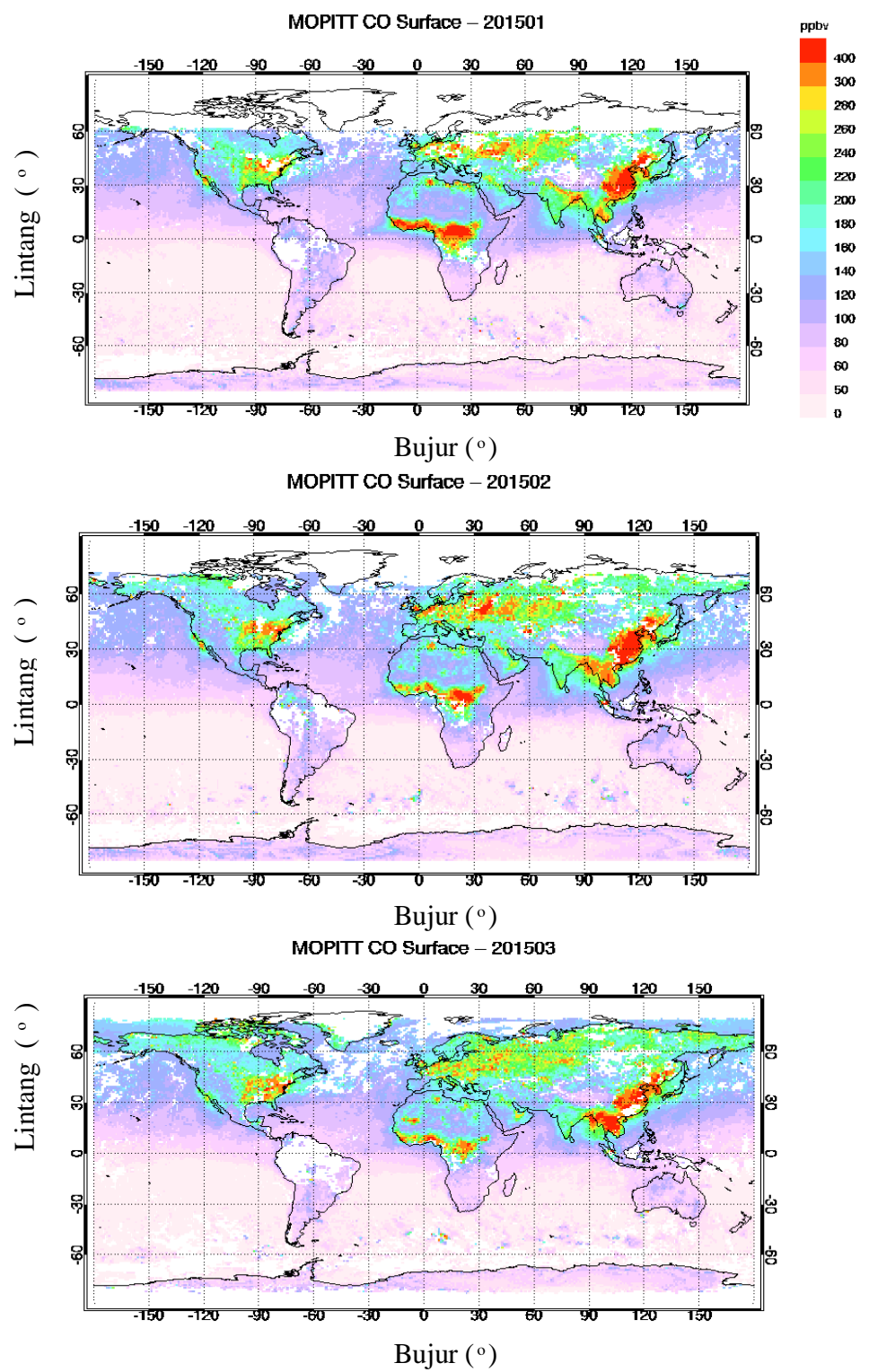

Gambar 3 Plot rata-rata CO permukaan (a) Januari, (b) Februari, (c) Maret tahun 2015 (Sumber : https://www2.acom.ucar.edu/mopitt, 2016)

Selain peningkatan $\mathrm{CO}$ pada saat kebakaran hutan, konsentrasi $\mathrm{CO}$ yang tinggi teramati selama Januari-April. Untuk mengetahui penyebab hal ini, diambil data CO permukaan di sekitar Sumatera. Gambar 3a, Gambar 3b maupun pada Gambar 3c memperlihatkan bahwa konsentrasi CO permukaan cukup tinggi pada lintang di atas ekuator atau daerah Thailand dan 
sekitarnya. Untuk mengamati pergerakan gas CO dari daratan Thailand ke Sumatera, maka diplot data CO harian selama Januari hingga April yang dirata-ratakan dalam grid 90BT-100 BT untuk tekanan $900 \mathrm{hPa}$ (Gambar 4a) dan $400 \mathrm{hPa}$ (Gambar 4b).
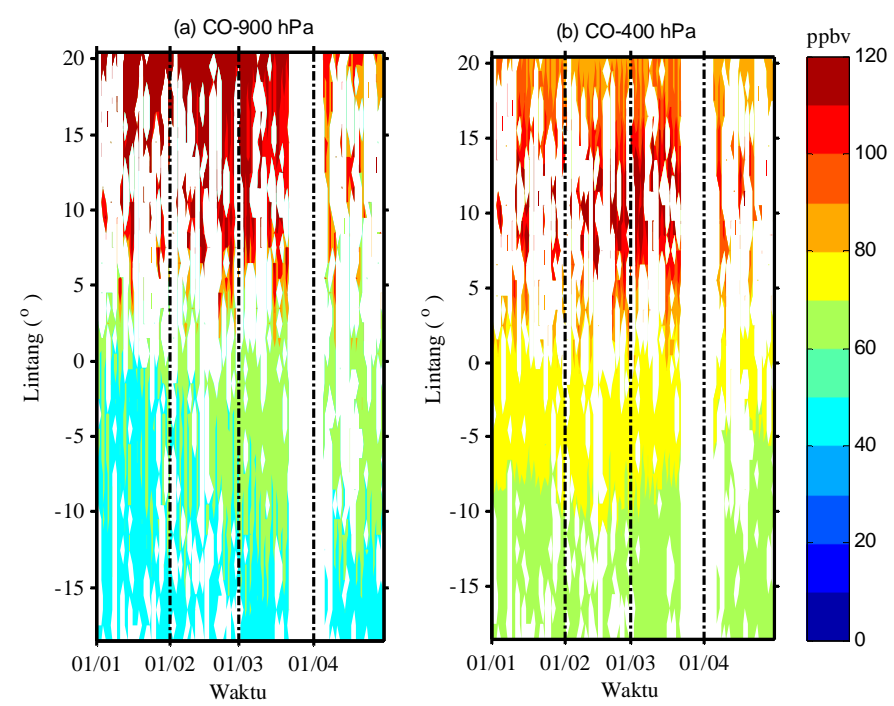

Gambar 4 Distribusi Spasial CO bulan Januari-April 2015 pada tekanan (a) $900 \mathrm{hPa}$, (b) $400 \mathrm{hPa}$

Pada Gambar 4a maupun Gambar 4b tidak terlihat adanya pergerakan CO dari wilayah Thailand ke Sumatera. Oleh karena itu, tingginya jumlah konsentrasi CO di bulan Januari hingga Maret diperkirakan disebabkan oleh faktor lain dan diperlukan penelitian lebih lanjut untuk mengetahui faktor-faktor tersebut.

\subsection{Studi Kasus Pengamatan Pengaruh Awan konvektif terhadap Distribusi Vertikal CO}

Hubungan antara distribusi vertikal CO dengan proses konvektif pada Gambar 2 belum terlihat jelas. Oleh sebab itu, diambil beberapa kasus untuk mengamati pergerakan $\mathrm{CO}$ akibat awan konvektif. Data yang dipilih adalah data MOPITT yang melewati daerah sekitar lintang Sumatera dan ketika awan konvektif terjadi selama kebakaran hutan di Sumatera. Awan konvektif didefinisikan jika nilai OLR $<220 \mathrm{~W} / \mathrm{m}^{2}$. Tanggal yang dijadikan studi kasus adalah tanggal 11,15, dan 27 Oktober 2015. Untuk melihat pergerakan arah vertikal (ke atas), diplot data $\mathrm{CO}$ untuk tekanan $900 \mathrm{hPa}, 400 \mathrm{hPa}$ dan $100 \mathrm{hPa}$.

Gambar 5, Gambar 6 dan Gambar 7 adalah data hasil pengamatan gas CO dan OLR pada 11 oktober, 15 Oktober dan 27 Oktober 2015. Dari ketiga kasus ini, terdapat dua hasil plot yang terlihat adanya hubungan antara distribusi vertikal $\mathrm{CO}$ dengan awan konvektif. Kedua plot tersebut adalah pada Gambar 5 (11 Oktober) dan Gambar 6 (15 Oktober) yang ditandai dengan kotak bewarna merah. Kedua kasus tersebut memperlihatkan terjadinya peningkatan jumlah gas CO dari tekanan $900 \mathrm{hPa}$ menuju $400 \mathrm{hPa}$ dan $100 \mathrm{hPa}$. Pada 11 Oktober, jumlah CO bertambah dari 60 ppbv menuju 80-100 ppbv. Plot tersebut mencakup sebagian kecil pulau Sumatera yaitu antara $2^{\circ}-20^{\circ}$ LU. Untuk kasus kedua pada tanggal 15 Oktober, jumlah gas CO juga mengalami peningkatan dari 60 ppbv menjadi 80-90 ppbv. Namun, hubungan antara distribusi vertikal CO dengan awan konvektif pada kasus ini berada di luar pulau Sumatera yaitu di sekitar Malaysia.

Berbeda dari dua kasus sebelumnya, hubungan antara distribusi vertikal CO dengan awan konvektif pada tanggal 27 Oktober (Gambar 7) tidak terlihat. Gambar tersebut memperlihatkan bahwa satelit MOPITT tidak melewati daerah Sumatera yang menjadi titik pengamatan dalam penelitian ini. Hal ini dikarenakan ukuran terkecil yang dapat dideteksi atau resolusi spasial MOPITT adalah 22 x $22 \mathrm{~km}$ dan interval waktu perulangannya cukup lama yaitu 4 hari (Canadian Space Agency, 2016). Selain waktu perulangan yang cukup lama, banyak missing data di daerah Sumatera sehingga menyebabkan kekosongan data. Oleh karena itu, hubungan antara distribusi $\mathrm{CO}$ ke lapisan troposfer atas dengan terbentuknya awan konvektif 
pada kasus ini tidak dapat diamati, walaupun data OLR menunjukkan terdapatnya awan konvektif di daerah Sumatera.

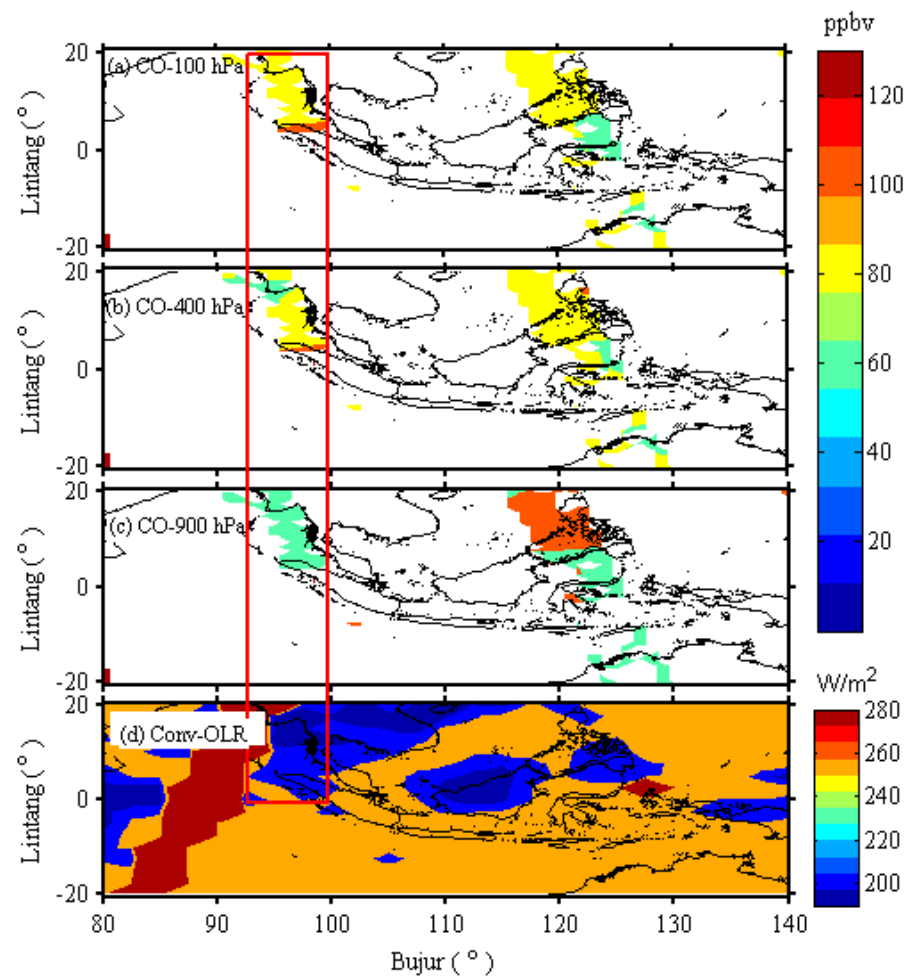

Gambar 5 Plot konsentrasi CO pada tekanan (a) 100hPa (b) $400 \mathrm{hPa}$, (d) $900 \mathrm{hPa}$ dan (d) OLR pada 11 Oktober 2015

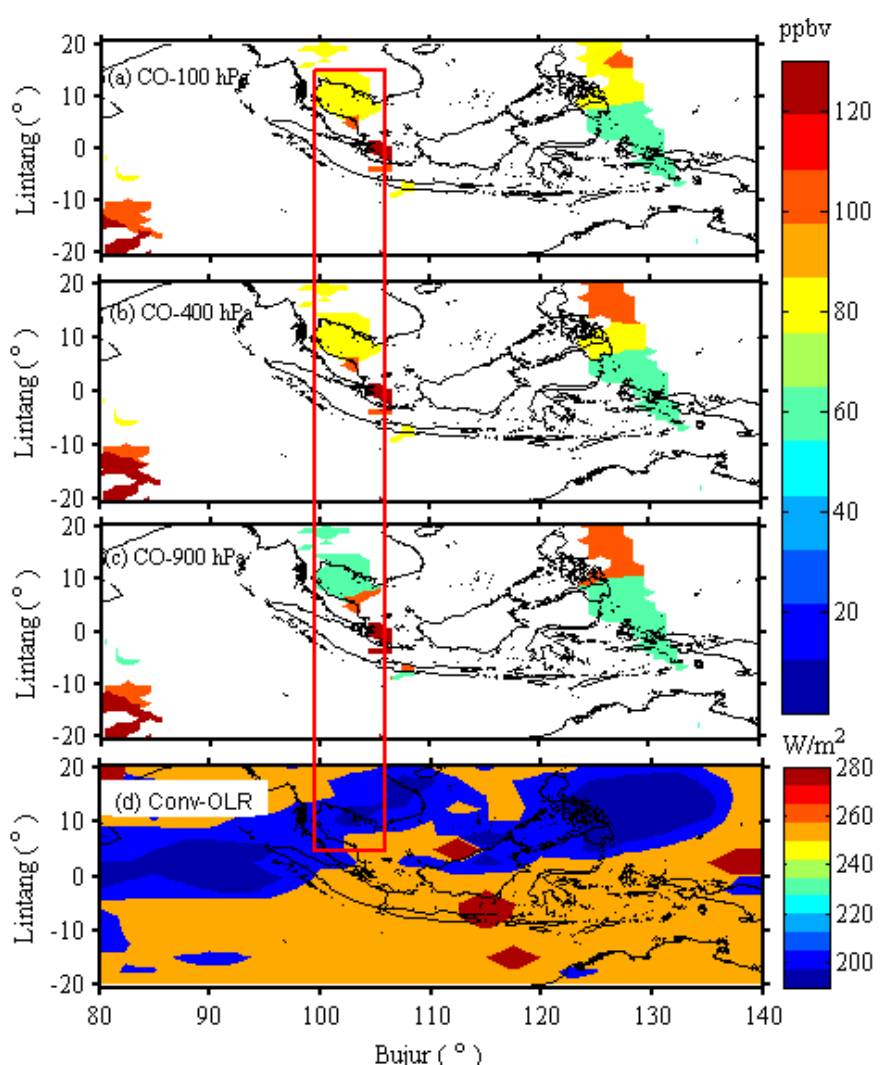

Gambar 6 Plot konsentrasi CO pada tekanan (a) 100hPa, (b) $400 \mathrm{hPa}$ (d) $900 \mathrm{hPa}$ dan (d) OLR pada 15 Oktober 2015 


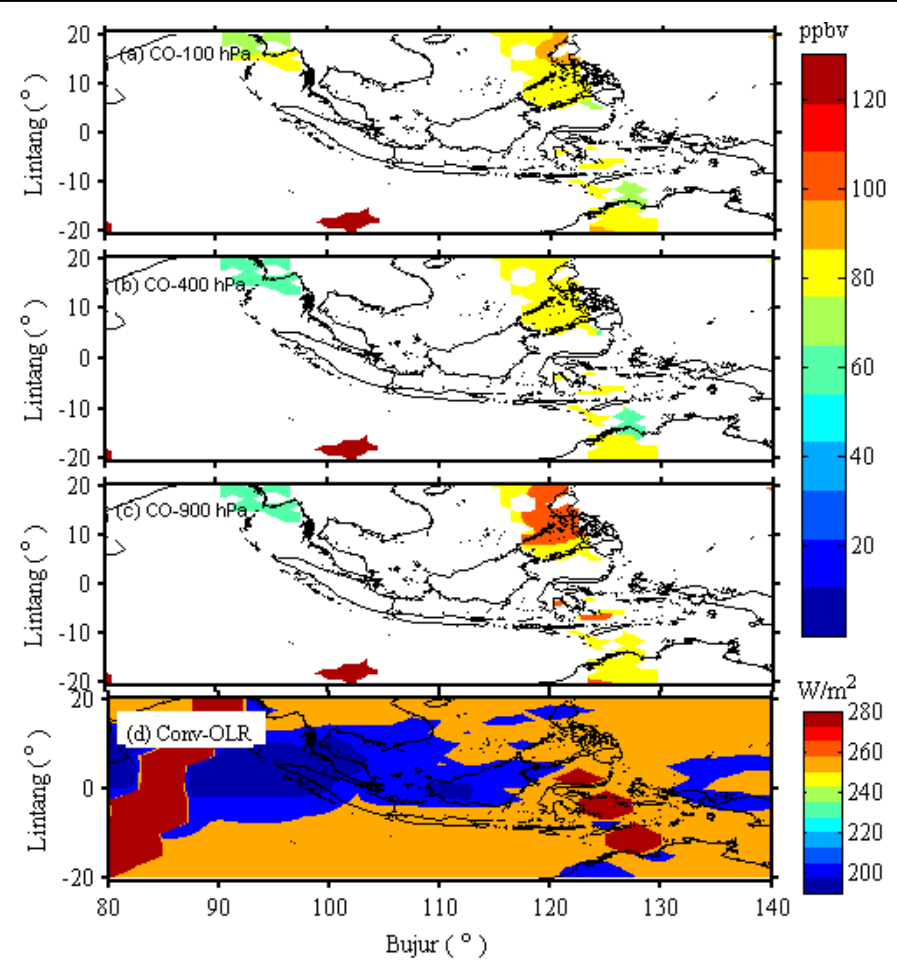

Gambar 7 Plot konsentrasi CO pada tekanan (a) 100hPa, (b) $400 \mathrm{hPa}$, (d) $900 \mathrm{hPa}$ dan (d) OLR pada 27 Oktober 2015

\section{KESIMPULAN}

Penelitian ini memperlihatkan bahwa kebakaran hutan selama tahun 2015 telah meningkatkan konsentrasi $\mathrm{CO}$ di Indonesia. Namun, jumlah gas $\mathrm{CO}$ yang terekam oleh MOPITT tidak terlalu tinggi hanya berkisar antara 40-120 ppbv. Hal ini disebabkan oleh tingginya konsentrasi uap air di kawasan ini sehingga konsentrasi CO rendah dan waktu tinggal $\mathrm{CO}$ di atmosfer juga berkurang. Selain di permukaan, peningkatan konsentrasi CO juga teramati pada lapisan atmosfer yang lebih tinggi. Namun, hubungan antara pergerakan $\mathrm{CO}$ ke lapisan atmosfer atas dengan aktivitas konvektif sulit untuk diamati dengan memanfaatkan data satelit MOPITT karena tidak begitu terlihat. Perulangan waktu pengamatan MOPITT untuk titik pengamatan yang sama yang cukup lama yaitu 4 hari menjadi salah satu kendala. Walaupun demikian, dari tiga studi kasus yang diteliti, teramati pengaruh konvektif terhadap pergerakan CO ke atas pada dua kasus yaitu tanggal 11 dan 15 Oktober 2015. Pada 11 Oktober, jumlah CO bertambah dari 60 ppbv menuju 80-100 ppbv sedangkan pada tanggal 15 Oktober, jumlah gas CO mengalami peningkatan dari 60 ppbv menjadi 80-90 ppbv pada $100 \mathrm{hPa}$.

\section{DAFTAR PUSTAKA}

Canadian Space Agency, 2016, Measurements of Pollution in the Tropospher, Kanada.

Girach I.A. dan Nair, P.R., 2014a, Carbon Monoxide over Indian Region as Observed by MOPITT, Atmospheric Environment, Vol. 99, Hal. 599-609.

Girach, I.A. dan Nair, P.R., 2014b, On the Vertical Distribution of Carbon Monoxide over Bay of Bengal during Winter : Role of Water Vapour and Vertical Updrafts, Journal of Atmospheric and Solar-Terrestrial Physics, Vol. 117, Hal. 31-47.

Gonzi, S., Feng, L., Palmer, P. I., 2011, Seasonal Cycle of Emissions of CO Inferred from MOPITT Profiles of CO: Sensitivity to Pyroconvection and Profile Retrieval Assumptions, Geophysical Research Letters, Vol. 38. Hal. 8813.

Kar, J., Bremer, H., Drummond, J.R., Rochon, Y.J., Jones, D.B.A., Nitchitiu, F., Zou, J., Liu, J., Gille, J.C., Edward, D.P., Deeter, M.N., Francis, G., Ziskin, D., Warner, J., 2004, Evidence of Vertical Transport of Carbon Monoxide from Measurements of Pollution in the Troposphere (MOPITT), Geophysical Research Letters, Vol. 31. Hal. 23105-23109. 
Kumar, R., Naja, M., Pfister, G. G., Barth, M. C., Brasseur. G.P., 2013, Source Attribution of Carbon Monoxide in India and Surrounding Regions during Wintertime, Journal of Geophysical Research: Atmospheres, Vol. 118, Hal. 1981-1995.

Liu, J., Drummond, J.R., Li, Q., Gille, J.C., Ziskin, D.C., 2005. Satellite Mapping of CO Emission from Forest Fires in Northwest America using MOPITT Measurements, Remote Sensing of Environment. Vol. 95, No. 4, Hal. 502-516.

Marzuki, Hashiguchi, H., Yamamoto, M. K., Yamamoto. M., Mori, S., Yamanaka, M. D., Carbone, R. E., and Tuttle, J. D., 2013, Cloud episode propagation over the Indonesian Maritime Continent from 10 years of infrared brightness temperature observations, Atmospheric Research, Vol. 120-121, Hal. 268-286.

Marzuki, Hashiguchi, H., Kozu, T., Shimomai, T., Shibagaki, Y., Takahashi, Y., 2016a, Precipitation Microstructure in Different Madden-Julian Oscillation Phases over Sumatra, Atmospheric Research, Vol. 168, Hal. 121-138.

Marzuki, Hashiguchi, H., Shimomai, T., Randeu, W.L., 2016b, Cumulative Distribution of Rainfall Rate over Sumatra, Progress In Electromagnetics Research M, Vol. 49, Hal. 18

Mori, S., Hamada, J.I. , Tauhid, Y.I., Yamanaka, M. D., Okamoto, N., Murata, F., Sakurai, N., Hashiguchi, H., dan Sri bimawati, T., 2004, Diurnal Land-Sea Rainfall Peak Migration over Sumatera Island, Indonesian Maritime Continent, Observed by TRMM Satellite and Intensive Rawinsonde Soundings, Monthly Weather Review, Vol. 132, Hal. 2021-2039.

Richards, N.A.D., 2004, Characteristics of Tropospheric Carbon Monoxide Profiles Retrieved from Mopitt Measurements, Tesis, Department of Physics and Astronomy, University of Leicester, Leicester.

Rivanda, A., 2015, Pengaruh Paparan Karbon Monoksida terhadap Daya Konduksi Trakea, Majority, Vol. 4, No. 8, Hal. 153.

Srivastava, S. danSheel, V., 2013, Study of Troposphere CO and O3 Enhancement Episode over Indonesia during Autumn 2006 using The Model for Ozone and Related Chemical Tracers (MOZART-4), Atmospheric Environment, Vol. 67, Hal. 53-62.

Vadrevu, K. P., Giglio, L., Justice, C., 2013, Satellite Based Analysis Of Fireecarbon Monoxide Relationships From Forest And Agricultural Residue Burning (2003-2011), Atmospheric Environment, Vol. 64, Hal. 179-191.

Zulfa, A., 2011, UjiAdsorbsi Gas KarbonMonoksida (CO) Menggunakan Zeolit Alam Malang dan Lampung, Tesis, Teknik Kimia, Universitas Indonesia, Depok.

http://fires.globalforestwatch.org/map/\#activeLayers=activeFireSs, diakses Maret 2016.

https://www2.acom.ucar.edu/mopitt,diakses 2016 